\title{
Fire Risk Assessment of Adaptive Re-Use of Historic Shop Houses for Sleeping Accommodations in Malaysia
}

\author{
M.A.O. Mydin ${ }^{1, a}$, W. Arminda ${ }^{2}$, N. Md. Sani ${ }^{3}$ \\ ${ }^{1,2,3}$ School of Housing, Building and Planning, Universiti Sains Malaysia, 11800, Penang, Malaysia
}

\begin{abstract}
Heritage buildings were generally constructed without regard for fire risks or the requirements for fire protection, as are obligatory in new constructions. When a heritage building undergoes a change to its original function, improvements to the building's fire safety are necessary to meet the needs of possible increases in occupancy loads and to account for fire risks related to the new usage. This research focuses on fire safety risks, fire protection and safety systems as well as the rules and regulations that an adaptive reuse heritage shop house is bound to when transitioning to a sleeping accommodation, which, in this case, means becoming a hotel. In this research, six heritage shop houses were chosen as case studies. The objectives of this research were to evaluate current fire emergency plans as well as to identify and assess possible fire hazards created by adaptive reuse of heritage shop houses to sleeping accommodations in Penang through a series of observations and interviews. The results of the research show that most of the buildings were provided with inadequate fire safety systems.
\end{abstract}

\section{Introduction}

A heritage building is a building that is considered to have historical significance. Factors making a building historically significant include its aesthetic, historic, scientific, and social value which are embodied in the place itself. Also important are its materials, setting, use, association, meaning, records, and related places as well as its related objects [1]. Most heritage buildings were built prior to the formulation of the Uniform Building By-Laws of 1984. Hence, the buildings were not subjected to the provision of fire safety requirements provided by the by-law [2]. As such, many of these heritage buildings were built without much thought given to fire protection and resistance.

Fire is one of the most threatening hazards, not only to the building's occupants, but also to the building's structure and content. Fire has long been an adversary of heritage structures, with some older structures having falling victim many times. Despite this fact, fire safety is generally neglected.

George Town, selected as a UNESCO World Heritage Site in July 2008, has many types of historical buildings. One such type of historical building is the shop house. A shop house is a local architectural building type that generally has two or three storeys that was used as a residence on the upper floor and a shop on the ground floor. Shop houses in Penang have greatly developed over time. These types of buildings can be easily modified; their open, simple structure simplifies installation of utilities and facilitates change (houses along a row can be combined for expansion) [3]. Altering

${ }^{\text {a }}$ Corresponding author : azree@usm.my 
existing buildings for new functions is not a new concept. In the past, buildings that were structurally secure were adapted to fit changes in needs or new functions without theoretical reflections [4].

Adaptive reuse of heritage shop houses may be defined as modifying a building for use other than its original use for public access [5]. Through adaptive reuse, a heritage building may be rejuvenated in terms of both physical and economic value.

When upgrading and adapting a building for new use, the existing structure should be retained by strengthening and repairing its structural elements. Any alteration or strengthening to structural elements should be done in the most sympathetic and non-destructive way possible. Original methods and materials should be used whenever possible, or matching materials of similar properties, if originals cannot be preserved. If a building is deemed unsafe, it should be made safe following original methods and materials [6], and it should fulfil the UBBL requirements, especially in terms of its fire safety system.

In the event that a heritage shop house is changed into sleeping accommodations for guests, the particular characteristics of the building's layout and occupants need to be known in order to reduce the fire risk to an acceptable level. People are particularly vulnerable to the effects of smoke and toxic fire gases when they are asleep. They are especially at risk as they might not be very familiar with the premises and escape routes. Guests may be tired after travelling for many hours or they may be deeply asleep, having gone to bed late after a heavy meal and/or having consumed alcohol, all of which might leave them in a disorientated state when being suddenly awakened by, for example, the sound of a fire alarm.

The Fire and Rescue Department of Malaysia (FRDM) reported cases of fire which happened to heritage buildings in Penang during 2013. There were 26 cases of fire, 14 (53.8\%) of which happened in shop houses.

Table 1: Fire cases reported in heritage buildings in Penang during 2013

\begin{tabular}{|c|c|c|c|c|}
\hline DATE & $\begin{array}{l}\text { TYPES OF } \\
\text { BUILDING }\end{array}$ & LOCATION & $\begin{array}{l}\text { TOTAL EST. } \\
\text { LOSS }\end{array}$ & CAUSE \\
\hline $7 / 1 / 2013$ & Office Building & Queen St & - & Others \\
\hline $14 / 1 / 2013$ & Shop house & Penang Rd & > RM200.000 & Others \\
\hline $19 / 1 / 2013$ & Shop house & Penang Rd & RM10.000 & Others \\
\hline $23 / 1 / 013$ & Shop house & Hutton Rd & RM80.000 & Others \\
\hline $10 / 2 / 2013$ & Residential (Flat) & Sri Saujana & - & - \\
\hline $12 / 2 / 2013$ & Shop house & Beach St & $>$ RM75.000 & - \\
\hline $18 / 2 / 2013$ & Residential (Terrace) & Lebuh Nordin & RM50.000 & - \\
\hline $24 / 2 / 2013$ & Shop house & Jln C.Y Choy & $>$ RM1 million & - \\
\hline $24 / 3 / 2013$ & Store & - & RM5.000 & Others \\
\hline $29 / 3 / 2013$ & Workshop & Weld Quay & RM50.000 & Others \\
\hline $29 / 3 / 2013$ & Pre war temple & - & RM20.000 & Others \\
\hline $31 / 3 / 2013$ & Shop House & Jln Dr Lim Chee Leong & RM20.000 & Others \\
\hline $4 / 5 / 2013$ & Residential (Flat) & - & - & Kitchen Gas/oil \\
\hline $5 / 5 / 2013$ & Shop House & - & RM200 & Electricity \\
\hline $4 / 6 / 2013$ & Shop & - & RM2.000 & Arson \\
\hline $5 / 7 / 2013$ & Squatter house & - & RM103.000 & Others \\
\hline $8 / 7 / 2013$ & Shop House & & RM10.000 & Others \\
\hline $10 / 7 / 2013$ & Shop House & - & RM3.000 & Others \\
\hline $12 / 7 / 2013$ & Hall & - & RM5.000 & Others \\
\hline 24/8/2013 & Permanent House & - & RM100.000 & Others \\
\hline $19 / 9 / 2013$ & Permanent House & - & RM450.000 & Others \\
\hline $21 / 9 / 2013$ & Shop House & 74 Lebuh Gereja & RM450.000 & Others \\
\hline $4 / 10 / 2013$ & Shop House & Burma Road & RM450.000 & Others \\
\hline $5 / 10 / 2013$ & Shop House & - & RM450.000 & Others \\
\hline $28 / 10 / 2013$ & Shop House & - & RM10.000 & Others \\
\hline $30 / 10 / 2013$ & Shop House & - & RM10.000 & Others \\
\hline
\end{tabular}

(Source: Fire Rescue Department Malaysia, Beach Street, Penang, Malaysia, 2013) 
From the fire cases reported, it can be clearly seen that most took place in shop house, with a total loss of \pm RM2.318.200. Therefore, there is an urgent need to look into the fire safety aspects of heritage shop houses in Penang in order to determine the factors and causes than contributed to such a predicament.

\section{Methodology}

This research mainly focused on 6 heritage shop house units that have been adapted into sleeping accommodations, which, in this case, are hotels. From the pilot survey that was conducted, it was determined that there are around 60 heritage shop houses that have the same characteristics as were needed for the case study, thus, they were used as the population.

Since this type of research is qualitative, descriptive research, the size of the sample was based on $10 \%$ of the entire population according to recommendations by Gay and Diehl (1992) [7]. All the buildings were chosen randomly based on permission from the building owners. This condition also became a limitation for obtaining samples in this research.

All of the case studies fall into Heritage Building Category 2 and are located in the Core Zone area of George Town, Penang.

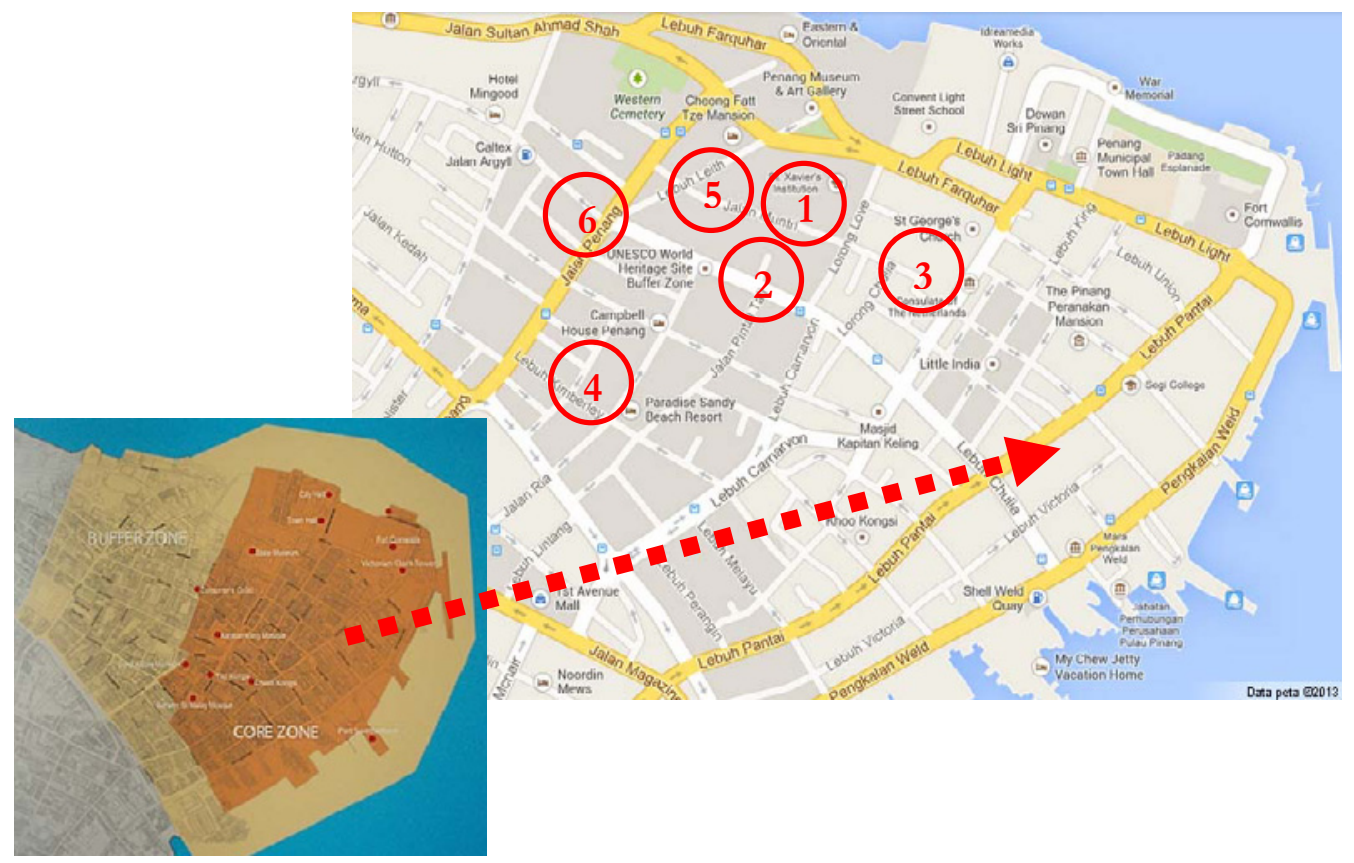

Fig. 1: Location of case studies in the core zone area

\section{(1) Red Inn Heritage (Fig. 2)}

Red Inn Heritage is a two storey shop house located at 15 Love Lane. The architectural style of the building is Early Straits Eclectic. It was built around 1880s-1920s and started operating as a hotel in 2011. The building has a total area of $\pm 644 \mathrm{~m}^{2}$ and provides 34 guest rooms.

\section{(2) Red Inn Penang (Fig. 3)}

This two storey building is of a Late Straits Eclectic style and was built around 1910s-1930s. It is located at 55 Love Lane and started as a hotel in 2010, offering 13 guest rooms with a shared bathroom. Red Inn Penang is adjacent to Lebuh Klang at the rear side and to other guesthouses on either side. The total area of this building is $\pm 156 \mathrm{~m}^{2}$. 


\section{(3) Red Inn Court (Fig. 4)}

Red Inn Court is a three storey building which is located on Masjid Kapitan Keling Street and is adjacent to a motor's shop on the right side. The owner inherited this building from relatives who formerly used it as a residence. There are 11 guest rooms in the Red Inn Court with a total building area of $\pm 108 \mathrm{~m}^{2}$.

(4) Rainbow Lodge 2 (Fig. 5)

Rainbow Lodge 2 is located at 98 Pintal Tali Street and is a two storey building that was built around 1910s-1930s with a Late Straits Eclectic architectural style. The building's owner still maintains the original façade and almost the entire structure of the building, which is a total area of around $120 \mathrm{~m}^{2}$. This building has 9 guest rooms which are separated by wooden partitions.

(5) Ryokan Chic Hostel (Fig. 6)

Ryokan Chic Hostel, located at 62 Muntri Street, is a three storey building with 16 guest rooms. This building has a total area of about $270 \mathrm{~m}^{2}$ and was renovated in March-April 2011 before being used as a hostel.

(6) Syok Hostel (Fig. 7)

Syok Hostel is a three storey building located at the corner of the meeting point of Chulia Street and Leith Street. With a Southern Chinese Eclectic style, this building started operating in February 2013 after being renovated. Standing on a piece of land of about $301 \mathrm{~m}^{2}$, this building provides 8 guest rooms with a shared bathroom. This building also rents out half of the ground floor to a Subway Restaurant.

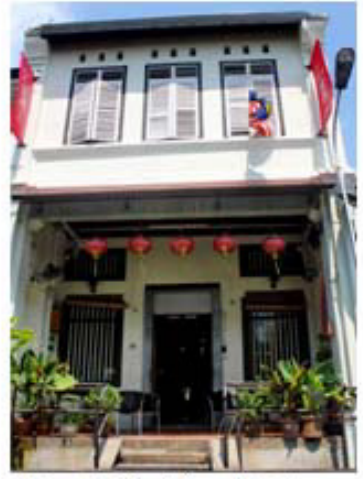

Fig. 2: Red Inn Heritage

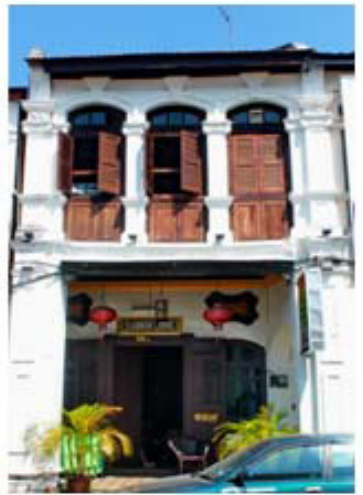

Fig. 5: Rainbow Lodge 2

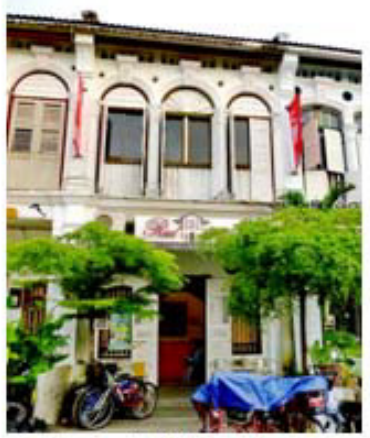

Fig. 3: Red Inn Penang

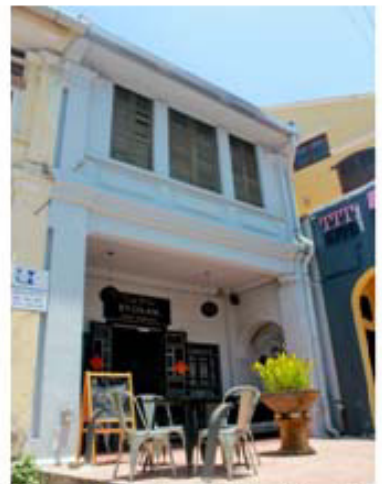

Fig. 6: Ryokan Chic Hostel

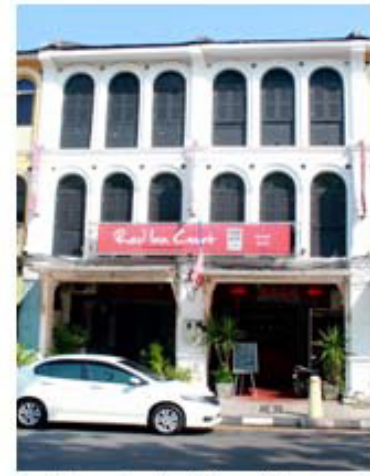

Fig. 4: Red Inn Court

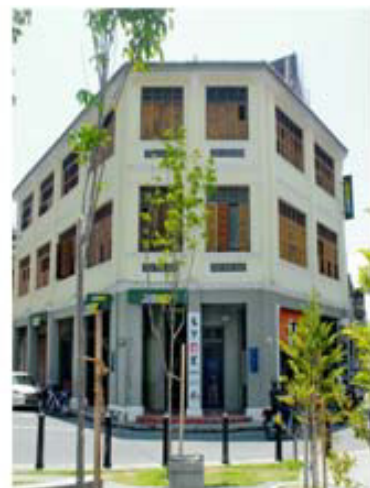

Fig. 7: Syok Hostel 


\subsection{Research Method}

This research is a qualitative case study which can allow researchers to explore or describe a phenomenon in context using a variety of data sources [8]. This ensures that the issue is not explored through one lens, but rather a variety of lenses which allows for multiple facets of the phenomenon to be revealed and understood [9]. To collect the primary data, observations were carried out directly at the aforementioned case study locations. Possible fire hazards as well as both passive and active fire safety systems were observed and photographed. Measurements of the buildings' layout or floor plan were also taken. During observations, all elements of fire safety had to be inspected. Observations were carried out over the course of several visits until all needed data was collected.

At the same time, some of the data comes from unstructured interviews with staff or those in charge in the building. By using unstructured interviews, the researchers/ interviewers were able to ask different questions to the interviewees without following a strict line of questioning. This was the best way to uncover important information [10] because the interviewees were willing to share insights that otherwise might not have been divulged. [11].

All of the data collected was very important in order for the researcher to identify existing conditions of fire safety within the buildings. The process of collecting the data was done in December 2013 and again in March 2014.

Since this research is a qualitative case study, all of data from site observations and interviews were analysed using descriptive analysis which included the creation of figures, tables and the building layouts for every case study. By using descriptive analysis, all the data can be described piece by piece and in depth. In this way, the existing fire safety conditions of the case study sites have been clearly laid out.

\section{Data Analysis and Discussion}

\subsection{Possible Fire Hazards}

After the analysis of fire safety risks was carried out, it was found that the most common hazard in every building came from the buildings' structure and materials. Highly combustible materials like timber for flooring, partitions, staircases, doors and windows were used. Due to the regulations restricting extreme modifications on heritage shop houses along with the desire to preserve the original features of the building to attract tourists coming to Penang, owners try to maintain the existing building.

All of the buildings are non-smoking areas and 5 of 6 buildings do not provide a kitchen, thus, the open flame hazard is reduced. The Red Inn Penang is the exception with a kitchen containing a gas stove to serve meals to their guests, while the other premises use electrical appliances to serve meals. All the buildings have quite good wiring installation.

Rainbow Lodge 2 and Syok Hostel provide laundry service within the building using a washing machine and special linen storage for all fabrics. All cleanser liquids are kept in a special storage or safety area.

In terms of storage, most of the buildings, such as Red Inn Heritage and Rainbow Lodge 2, do not have a proper warehouse. Unused products are merely placed at the rear, thereby blocking the outer exit door.

\subsection{Passive Safety Systems}

\section{a) Party Walls}

Each case study location is separated from neighbouring buildings with more than $25 \mathrm{~cm}$ thick party walls on the right and left sides, rising above the upper roof surface. In the event of a fire, the thickness of the party wall can stop flames temporarily while the occupants evacuate from the building. 


\section{b) Emergency Exit Routes}

The width of the exit routes for all of the case studies, except Rainbow Lodge 2, meets the requirement that they not be less than $70 \mathrm{~cm}$ wide. Parts of the corridors located adjacent to the staircase in Rainbow Lodge 2 are only $60 \mathrm{~cm}$ wide. The exit routes in all of the buildings are clear from any obstacles and free from tripping and slipping hazards. Only Ryokan Chic Hostel needs to maintain the carpet covering its wooden floor surface to reduce the slipping hazard.

\section{c) Staircases}

Every case study had problems with their staircases, though issues were not found for all elements examined. The most commonly found elements not conforming to standards were the number of treads as well as height and width of treads. From all of the case studies, only Syok Hostel has complied with staircase requirements.

\section{d) Fire Doors}

Only Syok Hostel has installed a fire door. The fire door separates the staircase area from the private area (guest room).

e) Final Exit Doors

Four of the six buildings have installed a final exit door at the rear of the building. The back door of Red Inn Court is not intended as an exit point, but there are two exit points at the front side. Ryokan Chic Hostel only has one exit point which is also the main entrance. The exit doors in all of the buildings are locked with padlocks.

\section{f) Dead Ends and Travel Distances}

Most of the buildings meet the requirements for permissible dead ends in every room which is not more than $10 \mathrm{~m}$ according to the UBBL seventh schedule. The travel distances in most buildings do not exceed that which is permissible for buildings without sprinklers, which is no more than 30m, except for the ground floor of Ryokan Chic Hostel and Red Inn Heritage. Ryokan Chic Hostel exceeds the allowed travel distance because of the absence of a final exit door at the rear. Thus, all occupants must follow routes to the main door. For Red Inn Heritage, the excessive travel distance is due to the length of the building, which is more than 75 meters, as well as the lack of space on either side of the building, making it impossible to reduce the travel distance.

\section{g) Emergency Lighting}

Emergency lighting is provided along the exit route in each case study. However, for several buildings, the amount of provided emergency lighting is not adequate. As is the case at Rainbow Lodge 2, the lighting is only fitted under the staircase to brighten the ground floor while no lighting is provided on the $1^{\text {st }}$ floor. On the other hand, the amount of emergency lighting on the $1^{\text {st }}$ floor of Red Inn Heritage and Red Inn Court is inadequate because of the length of the building at Red Inn Heritage and the corners and aisles of Red Inn Court.

\section{h) Exit Signs, Fire Notices and Emergency Plans}

Exit signs are provided at every exit door and exit point within all of the buildings. However, in several buildings, the placement of the exit sign is quite confusing because they have been put in improper places. As at Red Inn Heritage, the exit sign is fitted on the rear door, but the rear is not the location of the final exit. Furthermore, at Ryokan Chic Hostel, the exit sign is fitted on a rear door which is deadlocked because there is no final exit door at the rear.

Only two of six buildings have fire emergency plans and fire action notices: Red Inn Court and Syok Hostel. 


\section{i) Smoke Ventilation Systems}

Original heritage shop houses generally contain an air well. However, if a building owner needs more space for their hotel rooms, the air well is often roofed with a skylight roof or a combination of a metal roof and a skylight. The air well area should facilitate smoke ventilation so that the smoke does not collect within the building. Only the roof of the air well area in Red Inn Penang can be opened manually. The actually purpose of this roof is for controlling the air conditioner.

\subsection{Active Safety Systems}

\section{a) Portable Extinguishers}

As an active safety system, all of the buildings have portable extinguishers, though these are the only fire fighting system. The portable extinguishers used are Type A fire extinguishers which are the correct type. The weight of the extinguishers that are used in most buildings is $9 \mathrm{~kg}$, but only Rainbow Lodge 2 provides $1 \mathrm{~kg}$ extinguishers. The portable extinguishers in all of the buildings were placed in prominent areas except one extinguisher in Red Inn Court which was located behind the partition used to cover the warehouse. However, the number of portable extinguishers provided in several buildings was not adequate for the size of the buildings.

\section{b) Fire Detection Systems}

Not all of the building provide smoke or heat detectors. Red Inn Court, Ryokan Chic Hostel and Syok Hostel are the only three buildings that have smoke detectors in every guest room within the building. Only Red Inn Heritage has provided a manual call point while the other buildings do not have one.

\section{c) Fixed Extinguishing Systems}

None of the owners in these case studies has installed a fixed extinguishing system for their building. The fire fighting system that is provided is merely portable extinguishers. Whereas, according to UBBL, the hose-reel system should be installed for 2-3 storey hotel buildings.

\subsection{Readiness of Human Sources}

In terms of owners' or building authorities' awareness of their staff's knowledge and ability when it comes to the implementation of fire safety, it was found that from the six buildings, there were only two that perform fire drills at least once a year. These are Ryokan Chic Hostel and Syok Hostel. Whilst the staff at Red Inn Court claimed that, even though they had not held fire drills, they understand how to use the extinguisher and they knew what actions to take in case of fire. On the other hand, most of the staff at Red Inn Heritage did not know how to use a fire extinguisher nor did they know what action to take in the event of fire.

\section{Conclusion}

The outcome of this research shows that many building owners are less responsive to the importance of a final exit door and they do not realize the importance of having a fire emergency plan or fire notices. Rather, they are content with simply providing portable extinguishers as the only measure of active fire protection. Most of the buildings that still retain their original condition have not achieved a high level of fire safety awareness. Such buildings are made up of more than $70 \%$ timber which is a highly flammable material. However, buildings that have been renovated also cannot be guaranteed to fulfil all requirements. From all of the selected case study locations, Syok Hostel has the best fire safety system conditions and fire awareness. This building nearly fulfils all fire safety requirements according to the UBBL. 


\section{Acknowledgement}

The authors would like to thank the funding bodies of this research: Universiti Sains Malaysia under USM Short Term Grant. No. 304/PPBGN/6312147

\section{References}

1. ICOMOS Burra Charter, 1999

2. Ibrahim, M.N., Ibrahim, M.S., Mohd-Din, A., Abdul-Hamid, K., Yunus, Yahya, R.M. Fire Risk Assessment of Heritage Building - Perspectives of Regulatory Authority, Restorer and Building Stakeholder. Procedia Engineering 2011;20:325-328

3. Fels, P.T., 2002. Conserving the Shophouse City. The Penang Story-International Conference

4. Plevoets, B., Cleempoel, K.V., 2012. Adaptive Reuse as a Strategy Towards Conservation on Cultural Heritage: A Survey of $19^{\text {th }}$ and $20^{\text {th }}$ Century Theories. IE International Conference.

5. Building Department Hong Kong. 2012. Practice Guidebook on Compliance with Building Safety and Health Requirements under the Buildings Ordinance for Adaptive Re-use of and Alteration and Addition Works to Heritage Buildings

6. Draft Special Area Plan, Georgetown, Historic Cities of the Straits of Malacca

7. Gay, L.R., and Diehl, P.L., 1992. Research Methods for Business and Management. Macmillan Publishing. New York

8. Yin, R.K., 2003. Case Study Research: Design and Methods ( $3^{\text {rd }}$ ed). Thousand Oaks, CA: Sage

9. Baxter, P., Jack, S., 2008. Qualitative Case Study Methodology: Study Design and Implementation for Novice Researchers. The Qualitative Report, Vol. 13, No. 4, 544-559

10. Dana, J., Dawes. R, Peterson, N., 2013. Believe in the unstructured interview: The persistence of an illusion. Judgement and Decision Making, Vol.8, No. 5, pp. 512-520

11. Corbin, J., Morse, J.M., 2003. The Unstructured Interactive Interview: Issues of Reciprocity and Risks When Dealing With Sensitive Topics. Quality Inquiry, Vol. 9, No. 3, 335-354 